\title{
Multiphasic Kinetics for D-Glucose Uptake by Assemblages of Natural Marine Bacteria
}

\author{
F. Azam ${ }^{1}$ and R. E. Hodson ${ }^{2}$ \\ 1 Institute of Marine Resources, A-018, Scripps Institution of Oceanography, University of California, San Diego, La Jolla, \\ California 92093, USA \\ 2 Department of Microbiology, University of Georgia, Athens, Georgia 30602, USA
}

\begin{abstract}
D-Glucose-6- $\left[{ }^{3} \mathrm{H}\right]$ uptake kinetics for marine microbial assemblages were multiphasic when the kinetics were determined over a broad concentration range $\left(10^{-9} \mathrm{M}\right.$ to $\left.10^{-3} \mathrm{M}\right)$. Maximum uptake velocity $\left(V_{\max }\right)$ and the sum of half saturation constant $\left(K_{t}\right)$ and ambient glucose concentration $\left(S_{n}\right),\left(K_{t}+S_{n}\right)$, increased gradually as the range of glucose concentration was increased. In all seawater samples examined the lowest $\left(K_{t}+S_{n}\right)$ values were $2-5 \times 10^{-9} \mathrm{M}$; highest values were as high as $5.9 \times 10^{-4} \mathrm{M}$. Simple diffusion into algae or bacteria cannot explain the non-linearity of kinetics curves. Removal of most algal cells did not change the kinetic pattern, and indirect estimates of diffusion into bacteria were too small to have greatly changed the uptake in $1 \times 10^{-9}-1 \times 10^{-5} \mathrm{M}$ range of glucose. The kinetic diversity of marine bacterial assemblages has implications in the cycling of dissolved organic matter in the varied concentration regimes presumably present in production microzones. Turnover times of the glucose pool at elevated concentrations were in the order of $10^{1}-10^{3} \mathrm{~h}$, suggesting that episodic high concentrations of substrate would diffuse out of the production microzones before significant uptake. Sustained concentration gradients might attract high $K_{\mathrm{l}}$ high $V_{\max }$ bacteria which might take up a significant fraction of substrate within the production zone. The observed kinetic diversity points to the need for a modified kinetic approach to account for the diversity of $K_{t}$ and $V_{\max }$.
\end{abstract}

\section{INTRODUCTION}

A tight coupling between production and utilization of dissolved organic matter (DOM) in the sea is suggested by the observations of extremely low levels of biologically labile compounds (Vaccaro et al,, 1968; Azam and Hodson, 1977; Bada and Lee, 1977). Concentrations of amino acids and sugars range from about $10^{-6}$ to $10^{-7} \mathrm{M}$. Bacteria are mainly responsible for DOM uptake (Williams, 1970, 1975; Azam and Hodson, 1977), and it is generally assumed that they are adapted to efficiently metabolizing nutrients from such low concentrations in seawater.

DOM is, however, heterogeneously introduced into the seawater both spatially and temporally, due to discontinuous distribution of the sources of production (Sheldon et al., 1972; Parsons, 1975; Jannasch, 1974). For example, high concentrations are expected near a phytoplankter that is decomposing or excreting organic compounds, or near a detrital particle undergoing hydrolysis. Partial loss of intracellular materials from prey damaged during predation may also create microzones of high DOM concentration (Lampert, 1978; Copping and Lorenzen, 1980). Other zones rich in organic matter include digestive tracts and possibly other parts of marine animals (Sieburth, 1976). Bacterial uptake and metabolism of DOM is likely to be influenced by such environmental heterogeneity and fluctuations.

It is of interest to determine whether bacteria adapted to varied DOM concentrations are in fact present in the seawater. We would also like to find out whether 'new' DOM is assimilated largely by bacteria within the enriched production microzones or whether much of it diffuses into the bulk phase to be utilized at great dilution. Such seemingly intractable questions are central to an understanding of the nature of coupling between DOM production and its utilization by bacteria. The problem might be approached indirectly by examining nutrient uptake kinetics of natural bacterial assemblages.

The kinetic constants expressing affinity $\left(K_{1}\right)$ and capacity $\left(V_{\max }\right)$ of membrane transport systems are designed to optimize the uptake of nutrients in 
response to the cell's metabolic needs and nutrient availability in the environment. If $K_{t}$ and $V_{\operatorname{lidx}}$ values are measured for bacteria in natural assemblages these values might reflect the nutrient regimes encountered in the bacterial environment. Another pertinent kinetic parameter is the substrate pool turnover time, $T_{t}$. Its measurement should indicate how fast bacteria can take up a substrate present in a production microzone at given concentration. This time-frame for uptake can then be compared with the rate of diffusion.

It is important that measurements be made with intact, minimally perturbed natural microbial assemblages. Cultured isolates are not suitable because isolation media are extremely selective (only about $0.1 \%$ of bacteria form colonies; Hoppe, 1976) and because cultured bacteria are probably in different nutritional and physiological states than the natural assemblages.

A powerful and widely used technique (kinetic approdch) developed for natural aquatic assemblages (Parsons and Strickland, 1962; Wright and Hobbie, 1965) treats the mixed microbial population as a finite number of equivalent uptake sites. This simplifying assumption of kinetic homogeneity justifies the use of enzyme kinetics model. Varied concentrations $[A]$ of radiolabelled substrate are added to subsamples of seawater and the rate of tracer uptake, $f / t(f=$ fraction of label taken up in time $t$ ) is determined at each value of [A]. If the ambient substrate concentration is unknown the concentration-dependence of uptake is analyzed by Wright-Hobbie linearization (Wright and Hobbie, 1965) of Michaelis-Menten equation, based on the relationship: $t / f=A / V_{\text {mat }}+\left(K_{t}+S_{n}\right) / V_{\text {mat } 2}$. A plot of $t / f$ versus [A] yields $V_{\text {Illax }},\left(K_{1}+S_{n}\right)$ and $T_{1}$. If $S_{n}$ is known then $K_{1}$ can also be calculated; otherwise $\left(K_{1}+S_{n}\right)$ is still a useful upper limit on $K_{i}$.

The simplified kinetic model applies to heterogeneous natural assemblages provided $[\mathrm{A}]$ is varied over a limited concentration range, preferably close to $S_{11}$. This condition was used and recommended by Wright and Hobbie (1966) and Williams (1973), and recently by Gocke (1977) and Wright and Burnison (1979). At low substrate concentrations the kinetic properties of bacteria with low $K_{t}$, important in turnover of DOM at the low bulk phase concentrations, are dominantly expressed. We, on the contrary, are interested in determining the existence and the expression of diverse $K$, and $V_{\text {max }}$ uptake system possibly reflecting adaptation to varied organic regimes. Thus, we determined the concentration dependence of substrate uptake over a broad range $\left(9.8 \times 10^{-11}\right.$ to $\left.1 \times 10 \mathrm{M}\right)$. The substrate chosen was D-glucose since it occurs consistently in seawater (Mopper et al., 1980) and is readily utilized by marine bacteria (Hamilton et al., 1966; Vaccaro and Jannasch, 1966; Azam and Hodson, 1977).

\section{MATERIALS AND METHODS}

\section{Sampling}

Seawater samples $(0.5$ to $10 \mathrm{~m}$ depth) were collected with $\mathrm{HCl}$ washed glass bottles. Samples were processed within $1 \mathrm{~h}$ of collection during which time they were kept in subdued light or in the dark and at or near ambient temperature. Sampling sites, locations and depths are in Table 1.

\section{D-Glucose Turnover Time}

The method was that of Wright and Hobibie (1965), except that $\left({ }^{3} \mathrm{H}\right)$ rather than $\left({ }^{14} \mathrm{C}\right)$ glucose was used. High specific activity of ${ }^{3} \mathrm{H}$-glucose allowed us to measure the turnover time (t/f) at very low concentrations of added glucose (A] (Azam and Holm-Hansen, 1973). Ten to thirty $\mathrm{ml}$ seawater (or vernal pool water) was placed in $50 \mathrm{ml}$ capacity $(29 \mathrm{~mm} \times 140 \mathrm{~mm}) \mathrm{HCl}$ washed Pyrex glass tubes. Teflon-lined screw-caps were used to close the tubes. The samples were temperature-equilibrated to within $2 \mathrm{C}^{\circ}$ of the ambient temperature. Mixtures of radiolabeled and unlabeled glucose were added to achieve the desired concentrations. Samples were incubated for 40-60 min, except

Table 1 Sampling locations, depths and dates

\begin{tabular}{|c|c|c|c|}
\hline Study site & Location & $\begin{array}{l}\text { Depth } \\
(m)\end{array}$ & Date \\
\hline End of Scripps Pier & $.3253^{\prime} \mathrm{N} 11715^{\prime} \mathrm{W}$ & 0.5 & $\begin{array}{l}7 / 23 / 79 / 7 / 29 / 79 \\
6 / 11 / 79 \\
1 / 5 / 81\end{array}$ \\
\hline $\begin{array}{l}\text { CEPEX (Controlled Ecosystem Population Experiment) } \\
\text { site, Saanich Inlet, British Columbid, Canada }\end{array}$ & $4840^{\circ} \mathrm{N} 123^{\prime} 29^{\prime} \mathrm{W}$ & 0.5 & \\
\hline Southern California Bight Studies (FCRG) Stutuon 104 & $325.3^{\prime} \mathrm{N} 11726^{\prime} \mathrm{W}$ & $0.5 ; 10.0$ & $6 \cdot 16-6.30: 76 \quad 226 \cdot 76$ \\
\hline $\begin{array}{l}\text { Desert Vernal Pools, Deep Canyon Desert Biolugical } \\
\text { Research Station }\end{array}$ & $33^{4} 43.3^{\prime} \mathrm{N} 116^{\prime} 224^{\prime} \mathrm{W}$ & 0.5 & $3 / 22 / 75$ \\
\hline Off San Onofre & $33^{\prime} 22^{\circ} \mathrm{N} 117^{\prime} 34^{\prime} \mathrm{W}$ & 0.5 & $9 / 17 / 74$ \\
\hline
\end{tabular}


where indicated, in the dark, followed by filtration on 0.22 or $0.45 \mu \mathrm{m}$ nominal pore diameter Millipore filters to collect the particulate material. Filters were radioassayed in a Beckman LS $100 \mathrm{C}$ liquid scintillation spectrometer using Aquasol ${ }^{\mathbb{R}}$ as the fluor. Quench corrections were made by the external standard ratio method, and the counts per minute (CPM) converted to disintegrations per minute (DPM).

\section{Adsorption Blanks}

Adsorption blanks were used for each sample by adding buffered formalin ( $2 \%$ final volume) before the radiolabeled substrate. It was possible that formalin, by affecting the surface properties of the organisms, could give erroneous blanks. $\mathrm{HgCl}_{2}\left(0.1\right.$ or $\left.1.0 \mu \mathrm{g} \mathrm{ml}^{-1}\right)$ gave blank values comparable to formalin but $\mathrm{HgCl}_{2}$ also could have affected the surface properties (by interaction with sulfhydryl groups?). At very low glucose concentration $\left(9.8 \times 10^{-11}\right.$ to $\left.1 \times 10^{-8} \mathrm{M}\right)$ we compared formalin blanks with those made by the addition of $1 \mathrm{mM}$ dinitrophenol (DNP), an uncoupler of oxidative phosphorylation, added $30 \mathrm{~min}$ before the addition of the radiolabeled substrate. There was no systematic difference between the two sets of blanks and no concentration dependence of the blank. Both formalin and DNP blanks were $2.4 \pm 1.6 \%(n=36)$ of the uptake in this concentration range. Blank 'uptake' was substracted from the experimental samples. Turnover times were calculated as $t / f$, where $f=$ fraction of the added radioactivity assimilated in time $t$ (h) (Wright and Hobbie, 1965).

\section{Uptake by the Bacterial Size Fraction}

Assimilation of D-glucose- $\left({ }^{3} \mathrm{H}\right)$ by the bacterial fraction ( $<0.6 \mu \mathrm{m}$ fraction; Azam and Hodson, 1977) was determined by incubating parallel replicate samples with ${ }^{3} \mathrm{H}$-glucose as for uptake measurements. One sample was filtered on $0.2 \mu \mathrm{m}$ pore size Nuclepore filter to determine total uptake; the second sample was filtered on $0.6 \mu \mathrm{m}$ pore size Nuclepore filter to determine the uptake by $>0.6 \mu \mathrm{m}$ organisms. Uptake by 0.6 $\mu \mathrm{m}$ filterable organisms was computed as the difference between the radioactivity retained by the $0.2 \mu \mathrm{m}$ filter and that retained by $0.6 \mu \mathrm{m}$ filter. One control experiment showed that the uptake by bacterial fraction thus computed did not differ significantly from experimental measurement of radioactivity in $0.6 \mu \mathrm{m}$ filtrates collected on $0.2 \mu \mathrm{m}$ pore size Nuclepore filters.

Filtration through $0.6 \mu \mathrm{m}$ pore size Nuclepore filter does not necessarily separate bacteria completely from other organisms. Azam and Hodson (1977) found that in Southern California coastal waters an average of $11 \%$ of chlorophyll a passed $0.6 \mu \mathrm{m}$ filters. Although no intact algal cells were seen microscopically this chlorophyll could be in broken algae, fragile microflagellates or in cyanobacteria (Sieburth, 1976; Watson et al., 1979). More importantly a variable fraction (depending on the water sample) of bacteria is retained by $0.6 \mu \mathrm{m}$ filter. Generally, about $10 \%$ of the total bacteria are retained, as determined by scanning electron- and epifluorescence microscopy (Ferguson and Rublee, 1976; Fuhrman, 1981).

\section{Respiration}

Respiration of glucose was measured using ${ }^{14} \mathrm{C}$ or ${ }^{3} \mathrm{H}$ glucose. ${ }^{14} \mathrm{C}$-Glucose respiration was measured essentially by the method of Harrison et al. (1971). D-Glucose-(U- $\left.{ }^{14} \mathrm{C}\right)$ was added to $50 \mathrm{ml}$ seawater samples in $125 \mathrm{ml}$ Pyrex glass acid-washed BOD bottles with ground glass stoppers. After incubatior. for $60 \mathrm{~min}$, under conditions as described for uptake, the ground glass stoppers were replaced quickly with rubber septa equipped with plastic wells containing $0.2 \mathrm{ml}$ phenethylamine and a piece of fluted filter paper to absorb carbon dioxide (and other acid-volatile substances). One $\mathrm{ml}$ of $2 \mathrm{~N} \mathrm{H}_{2} \mathrm{SO}_{4}$ was then injected through the septum and the samples allowed to stay overnight. The wells containing the filters were placed in scintillation vials and radioassayed after adding 10 $\mathrm{ml}$ Aquasol ${ }^{(\mathbb{B})}$ as the fluor. Parallel samples were filtered on $0.45 \mu \mathrm{m}$ Millipore filters to determine assimilation. Respiration was expressed as percentage of assimilation + respiration.

Respiration of " $\mathrm{H}$-glucose was measured in filtrates after collecting cells for measuring assimilation (as described). Two $\mathrm{ml}$ aliquots were placed in scintillation vials, with a fluted filter paper to increase the surface area for evaporation. The samples were distilled, at room temperature, under high vacuum $<0.1$ $\mathrm{mm} \mathrm{Hg}$ ). The distillate containing tritium labeled water and other volatiles was collected in a cold trap placed in liquid nitrogen, and radioassayed.

\section{Radiochemicals}

D-Glucose $6{ }^{3} \mathrm{H}$ (specific activity $33.99 \mathrm{Ci} \mathrm{mM}^{-1}$ ) in $90 \%$ ethanol was purchased from New England Nuclear, Boston, Massachusetts, USA. D-Glucose-U- ${ }^{14} \mathrm{C}$ (360 $\mathrm{mCi} \mathrm{mM}^{-1}$ ) was also from New England Nuclear. Aliquots of stock solutions were evaporated under a stream of dry filtered air and reconstituted in distilled water for use. These solutions were added in very small volumes $(10$ to $500 \mu l)$ to seawater samples, 
therefore the resulting salinity changes were not considered important.

\section{RESULTS}

The non-linear $t / f$ versus [A] plot in Fig. $1 \mathrm{~A}$ represents the general kinetic pattern for a large number of seawater samples examined by us. Fig. 1B shows the plots for $>0.6 \mu \mathrm{m}$ and $<0.6 \mu \mathrm{m}$ fractions from the same experiment as in Fig. 1A. Clearly, the bacterial fraction itself shows kinetic diversity as reflected in the multiphasic nature of the kinetic curve. The lowest range of (A) yields $\left(K_{1}+S_{n}\right)$ of $2.5 \times 10^{\prime \prime} \mathrm{M}$ whereas the highest two points can be extrapolated to a much higher $\left(K_{1}+S_{n}\right)$ of $1.2 \times 10^{-6} \mathrm{M}$. Since these are subsamples from the same seawater sample, $S_{n}$ $\left(<2.5 \times 10^{-9} \mathrm{M}\right)$ is equal in all sub-samples. Increase in $\left(K_{1}+S_{n}\right)$ is therefore due to the increase in $K_{1}$.

The $>0.6 \mu \mathrm{m}$ fraction also yielded multiphasic kinetics. This fraction accounted for only $5-9 \%$ of the tota]

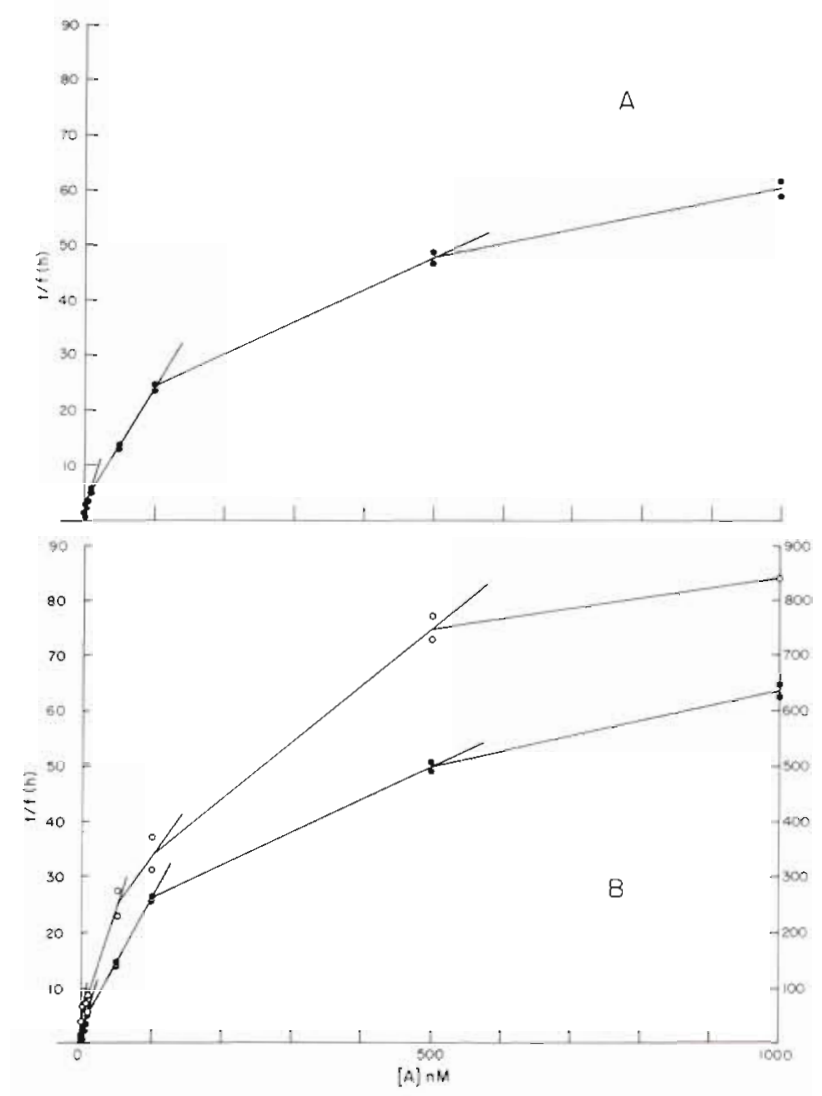

Fig. 1. Wright-Hobbie plots for D-glucose assimilation in a seawater sample collected from $0.5 \mathrm{~m}$ depth at a station $10 \mathrm{~km}$ offshore at Station 104 in the Southern California Bight. (A) Substrate turnover times, $t / f$, plotted against elevation in glucose concentration [A], for unfractionated sample; (B) for population divided into $<0.6 \mu \mathrm{m}(\bullet$ left ordinate $)$ and $>0.6$ lim (o, right ordinate) fractıons

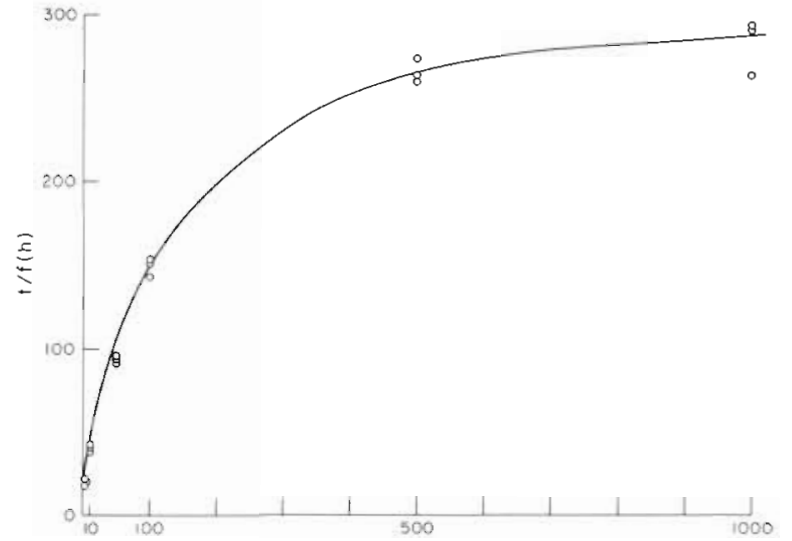

[A] $\mathrm{nM}$

Fig. 2. Wright-Hobbie plot for D-glucose assimilation in a seawater sample collected from a depth of approximately 0.5 $\mathrm{m}$, about $0.5 \mathrm{~km}$ offshore from San Onofre

uptake. Since about $10 \%$ of the bacterla are retanned by $0.6 \mu \mathrm{m}$ filters (Ferguson and Rublee, 1976; microscopic observations were not done here), part or all of uptake by $>0.6 \mu \mathrm{m}$ fraction may also be by bacteria.

Multiphic kinetics were also observed for near-shore samples (Fig. 2). Two samples from 2 highly eutrophic desert pools showed near-perfect linearity of kinetic plots in the same range of $[A]$ as for seawater samples (Fig 3), indicating the dominance of bacteria with identical or very similar kinetic properties. $K_{t}$ values of these assemblages were high (75 nM and $500 \mathrm{nM}$ ) compared with the high affinity components of marine assemblages.

In most seawater samples extrapolation from $[\mathrm{A}]=$ $10^{-4}-10^{-8} \mathrm{M}$ yielded $\left(K_{\mathrm{f}}+S_{i t}\right)$ of $2-5 \times 10^{-9} \mathrm{M}$ (e.g.

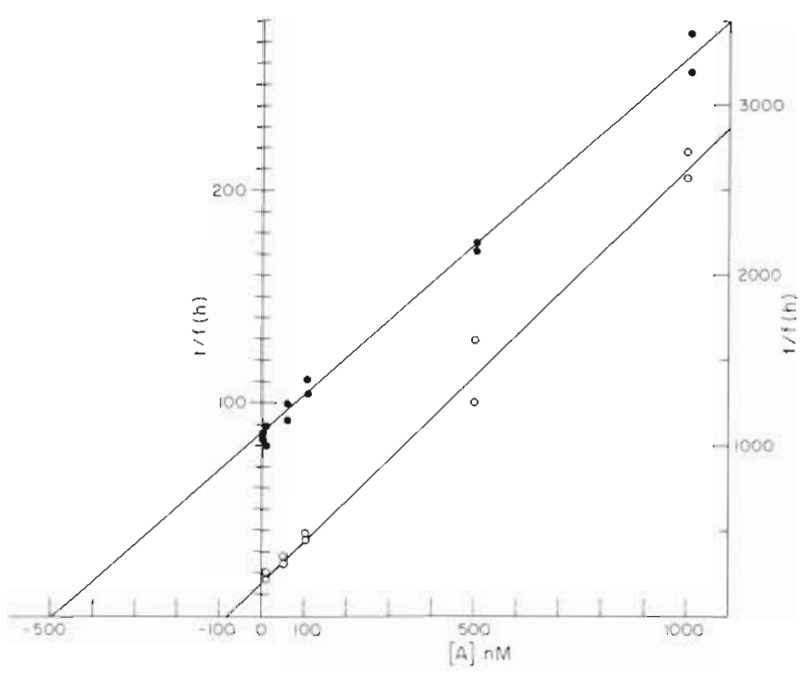

Fig. 3. Wright-Hobbie plot for D-glucose assimilation kinetics of the natural microbial population of two fresh water ponds at Palm Desert, California. $t / f$ : turnover time; [A]: added glucose. - - upper permanent pool, left ordinate; o - lower permanent pool, right ordinate 


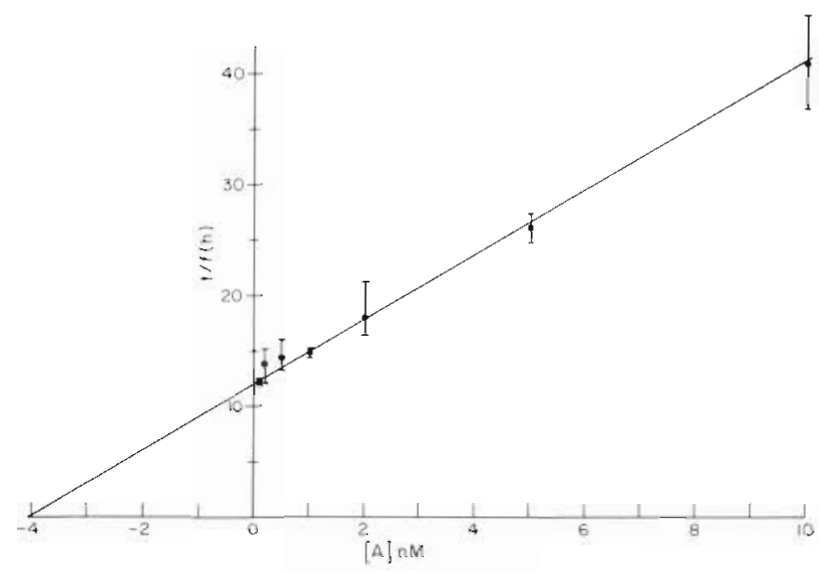

Fig. 4. Wright-Hobbie plots for D-glucose assimilation at low concentrations $\left(9.8 \times 10^{-11}-1 \times 10^{8} \mathrm{M}\right)$ of added glucose, for a sample of water taken from a depth of $10 \mathrm{~m}$ at SCBS station $104(10 \mathrm{~km}$ offshore $)$. $t / f$ : turnover time; [A]: added glucose

Fig. 1). We could not measure $S_{n}$ at such low levels for lack of a sufficiently sensitive analytical method. Therefore we can only say that $K_{t}$ was less than the measured $\left(K_{t}+S_{n}\right)$ of $2-5 \times 10^{-9} \mathrm{M}$. We considered that there may be bacteria in seawater with subnanomolar $K_{i}$, the presence of which might be revealed by uptake kinetics at the subnanomolar range of glu-

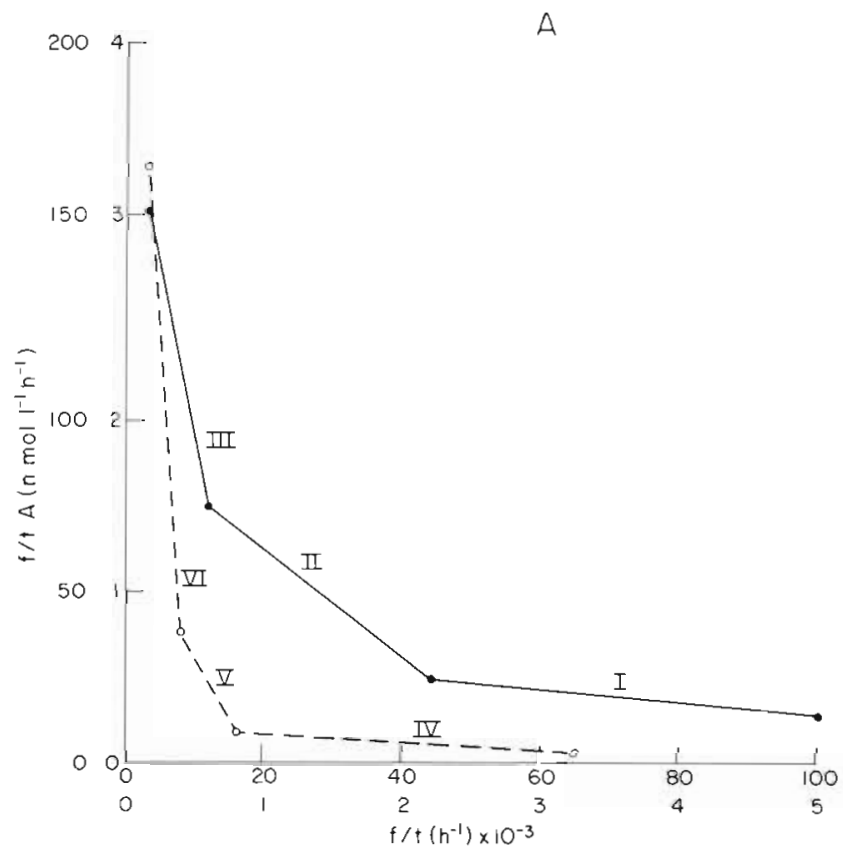

cose. When we added glucose at $9.8 \times 10^{-11} \mathrm{M}-$ $1 \times 10^{-8} \mathrm{M}$, a single straight line described the uptake kinetics $\left(\mathrm{r}^{\prime}=0.986\right)$ and did not reveal a lower $K_{t}$ system (Fig, 4). We could not rule out, however, that subnanomolar $K$, uptake systems were present but saturated at the ambient glucose concentration. Ambient concentration might have approached $4 \times 10^{-4} \mathrm{M}$ (the value of $K_{t}+S_{n}$ computed from the kinetic plot).

Extending the upper range of glucose concentration indicated the presence of very high $K_{1}$ uptake systems. Here, concentration was varied from nanomolar to millimolar and $t / f$ for both the $<0.6 \mu \mathrm{m}$ and $>0.6 \mu \mathrm{m}$ fractions were measured. Data for only $<0.6 \mu \mathrm{m}$ fraction are presented (Fig. 5), since uptake by $>0.6 \mu \mathrm{m}$ fractions (5-9\% of total uptake) could have been due to both bacteria and algae. $\left(K_{1}+S_{n}\right), V_{\text {nax }}$ and $T_{1}$ were computed from Wright-Hobbie plots of each two adjacent concentration points one order of magnitude apart. We assumed that first order kinetics are obeyed (linear plots) for one order of magnitude variation in [A], as has been reported by many investigators (Wright and Hobbie, 1965; Vaccaro and Jannasch, 1966; Gocke, 1977). $\left(K_{1}+S_{n}\right)$ increased from $2.3 \times 10^{-19} \mathrm{M}$ to $5.9 \times 10^{-4} \mathrm{M}$ over the range of $[\mathrm{A}]$ examined. This increase is due to increase in $K_{1}$

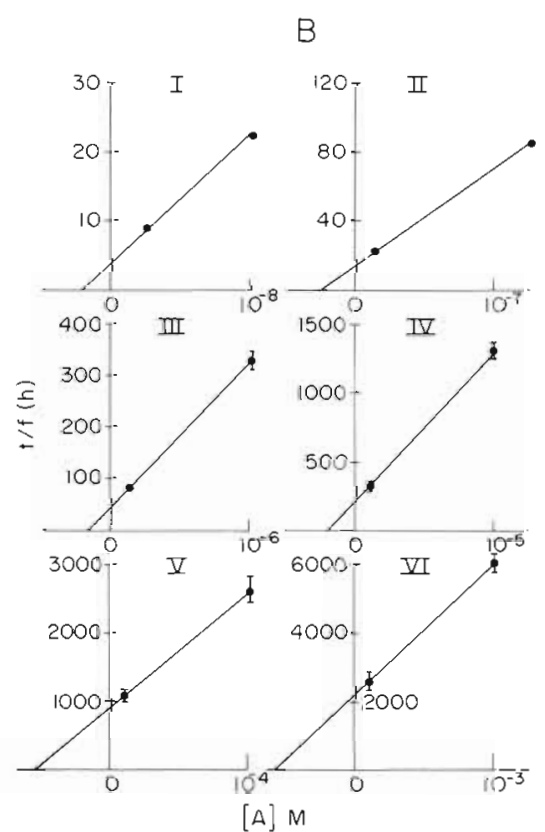

Fig. 5. (A) Modified Eadie-Hoftsee plot of D-glucose assimilation data for a sample of water taken from the end of Scripps Pier Concentration of added glucose $[\mathrm{A}]$ was varied from $2.5 \times 10^{4} \mathrm{M}$ to $1 \times 10^{-3} \mathrm{M}$. f/t: fraction of total glucose pool assimilated per h. Each point represents the average of 3 determinations. Slope $=-\left(K_{1}+S_{n}\right)$; y intercept $=V_{\text {inax }}$ x intercept $=1 / T_{1}\left(S_{n}=\right.$ ambient concentration; $K_{l}=$ uptake constant; $V_{\text {ild }}=$ maximum uptake rate; $T_{t}=$ turnover time at the ambient concentration). Numbers I-VI indicate the concentration ranges from $2.5 \times 10^{-9}-1 \times 10^{-8} \mathrm{M}$ (I) to $1 \times 10^{-3} \mathrm{M}$ (one order of magnitude steps). Only assimilation by $<0.6 \mu \mathrm{m}$ fraction is plotted. (B) Wright-Hobbie plots. Data points for each order of magnitude change in [A] are plotted on a separate graph, for clarity; representing all points on one graph compresses all but the highest concentration points, thus making it difficult to discern non-linearity. Linearity between each two points is assumed. Numbers I-VI refer to concentration ranges as in $(A)$ 
because $S_{n}$ is the same in all sub-samples. We assume here that uptake via sample diffusion was negligible in the bacterial size fraction (see Discussion).

In computing $K_{1}, V_{\max }$ and $T_{1}$ in Fig 5 , we realized that there would be overlap of kinetic curves representing different $K$, systems (e.g. Nissen, 1977) No attempt was made to correct for it because we did not know how many uptake systems were involved and whether some systems might exhibit negative cooperativity (Levitzki and Koshland, 1969). Computed kinetic parameters are therefore approximate, but they serve the intended purpose of demonstrating kinetic diversity.

The kinetic diversity can be visualized clearly in Eadie-Hoftsee plot of the same data (Fig. 5). This linear transformation of Michaelis-Menten equation is particularly useful for demonstrating the presence of multiphasic kinetics since it distributes the data points more evenly than other linear transformations (Eadie, 1952; Hoftsee, 1952) The plot is based on the following form of the Michaelis-Menten equation:

$$
\begin{aligned}
& v=-K_{1}(v / S)+V_{\max } \\
& \text { Putting } v=\frac{f}{t}\left(S_{n}+A\right) \text { and } S \\
& \frac{f}{t}\left(S_{n}+A\right)=-K_{t} \frac{f}{t}+V_{\max } \\
& \frac{f}{t} A=V_{\max }-\frac{f}{t}\left(K_{t}+S_{n}\right)
\end{aligned}
$$$$
\text { Putting } v=\frac{f}{t}\left(S_{n}+A\right) \text { and } S=\left(S_{n}+A\right) \text { in (1) }
$$

A plot of $[f / t \quad A]$ (y-axis) against $f / t$ (x-axis) yields a straight line; $x$-intercept $=V_{\text {max }} /\left(K_{t}+S_{t}\right) ; y$-intercept $=V_{\text {max }} ;$ slope $=\left(K_{t}+S_{n}\right)$. The modified Eadie-Hoftsee plot clearly shows a progressive increase in the slope (increasing $K_{i}$ )

Another point to notice (Fig 5B) is that the turnover time of the glucose pool after enrichment with $2.5 \times 10^{-47} \mathrm{M}$ glucose is $9.5 \mathrm{~h}$ but increases gradually to $6091 \mathrm{~h}$ at $10^{-3} \mathrm{M}$ glucose. Thus despite increase in assemblage uptake rate via high $K_{t}$ high $V_{\text {max }}$ systems it still takes a very long time to turnover enriched substrate pools compared with ambient substrate pools.

We considered that non-linearity of $t / f$ versus [A] plots could be an experimental artifact. If metabolic shift-up occurred at high but not at low glucose concentrations $t / f$ at high concentrations would be underestimated, and thus a decreasing slope with increasing [A] will result. Fig. 6 shows that turnover time remained constant for $2 \mathrm{~h}$ at all glucose concentrations.

Respiration was not accounted for in $t / f$ measurements. If this were a constant fraction of uptake at all concentrations its inclusion should not affect the shape of the kinetic curves; if percentage respiration changes with glucose concentration the shape of the curves

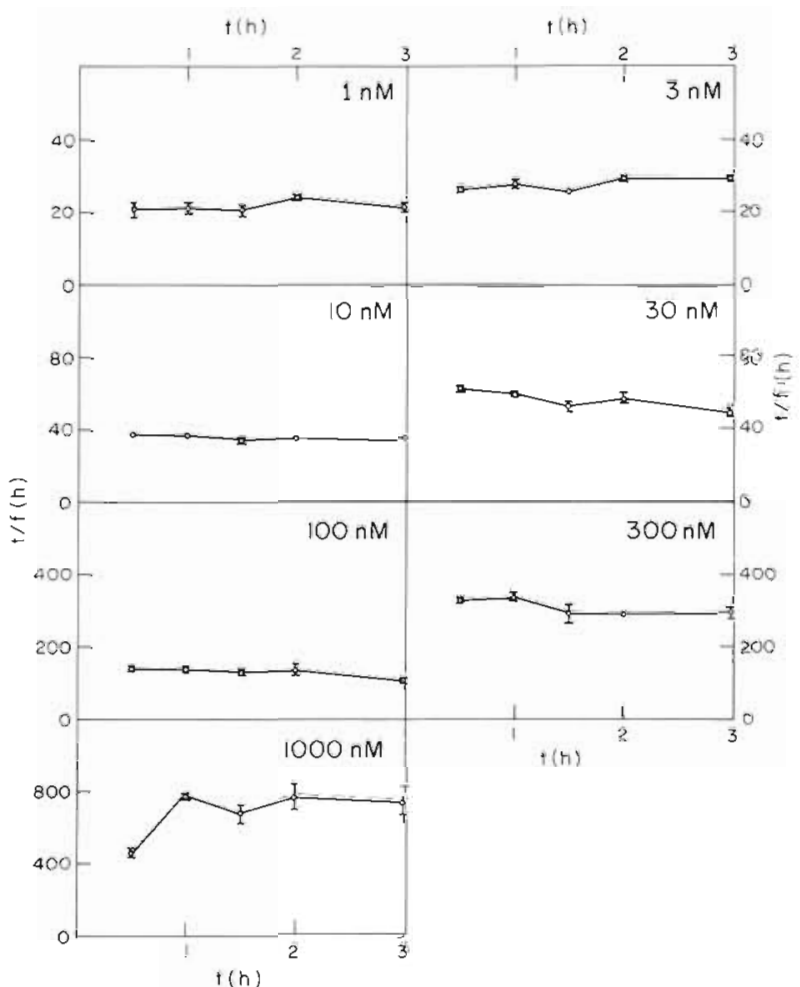

Fig. 6. Variation of $t / f$ with time of incubation for a natural microbial population collected from a depth of $0.5 \mathrm{~m}$ in Saanich Inlet. Measurements were done at different levels of added glucose, from $1 \times 10^{\prime \prime} \mathrm{M}$ to $1 \times 10^{\circ} \mathrm{M}$

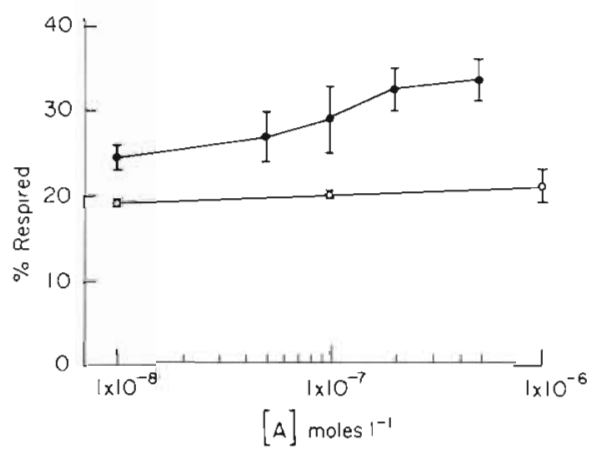

Fig. 7 Concentration dependence of glucose respiration. $\%\left[{ }^{14} \mathrm{C}\right]$ respired to $\left[{ }^{14} \mathrm{CO}\right]$ from added $\mathrm{D}$-glucose- $\mathrm{U}-\left[{ }^{14} \mathrm{C}\right]_{i}-$ $\%{ }^{3} \mathrm{H}$ respired to $\left[{ }^{3} \mathrm{H}\right]_{2} \mathrm{O}$ from added $\mathrm{D}$-glucose-6- $\left[{ }^{\prime} \mathrm{H}\right]$. Sample of seawater from the end of Scripps Pier, at $0.5 \mathrm{~m}$ depth

would be affected. Respiration was low in the nanomolar range (17-18\% respired) and increased with [A], becoming constant (25-28\% respired) at $5 \times 10^{-4} \mathrm{M}$ glucose (Fig. 7). Correcting for respiration will increase, not decrease, the non-Jinearity of the kinetic curves by decreasing $t / f$ more in the high range of $[A]$ than in the low range. Respiration measured with ${ }^{\prime} \mathrm{H}$ glucose was comparable $(19-21 \%$ respired) to measurements with ${ }^{14} \mathrm{C}$-glucose. 


\section{DISCUSSION}

Wright and Hobbie (1966) obtained non-linear curves for glucose uptake similar to ours for fresh water Lake Erken, Sweden. At a low concentration range $\left(8.5 \times 10^{9} \mathrm{M}\right.$ to $6.1 \times 10^{-\beta} \mathrm{M}$; estimated from their Fig. 5) the uptake data fitted their linear transformation of the Michaelis-Menten equation. At a much higher concentration range the slope decreased greatly as in our plots. They interpreted the decrease in slope as due to superposition of a low $K_{l}$ (bacterial) and a simple diffusion (algal) uptake system. Bennett and Hobbie (1972) suggested that these non-linear kinetics may have been due to the co-occurrence of low $K_{l}$ bacterial and high $K_{t}$ algal transport systems. Our results indicate that multiphasic uptake kinetics are largely caused by the presence of bacteria with very low (nanomolar) to very high (millimolar) $K_{\text {, glucose }}$ transport systems. High $K_{1}$ algae may also be present, but their contribution to glucose uptake was not significant

It is exceedingly difficult to make a mechanistic distinction between simple diffusion and mediated transport in a mixed microbial population. Direct measurement of simple diffusion is not possible because of overlap with mediated transport, unless one (arbitrarily) sets an upper limit on the concentration at which all saturable systems are assumed to be saturated.

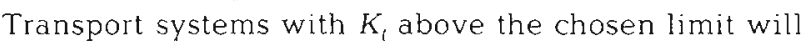
operationally be considered along with simple diffusion. Since our objective was to determine the range of $K$, value of marine bacterial assemblages it would not be logical to set an arbitrary limit on the highest $K_{1}$ anticipated. It was necessary for our purpose therefore to determine the effect of simple diffusion on the overall uptake kinetics.

Removal of algae by filtration on 0.6 um filter did not change the general shape of the kinetic curves (and hence the range of $K_{1}$ values of the bacterial size fraction). It was therefore unlikely that multiphasic uptake kinetics in unfractionated samples were caused significantly by algal uptake (via simple diffusion or

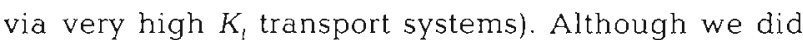
not check for it, some algae might have passed $0.6 \mu \mathrm{m}$ filter (Azam and Hodson, 1977). However, only 5-9\% of glucose assimilation at all values of [A] (Figs 1 and 5) was by the $>0.6 \mu \mathrm{m}$ fraction, although this fraction contained perhaps $90 \%$ of all algae and about $10 \%$ of bacteria (Ferguson and Rublee, 1976). Glucose uptake by any algae in bacterial fraction must therefore be negligible (unless the contaminating algae assimilated glucose greatly out of proportion to those retained by $0.6 \mu \mathrm{m}$ filter)

Simple diffusion into bacteria could have influenced the uptake kinetics of saturable systems. M a x i m u m contribution of $v_{d}$ (uptake velocity by simple diffusion) to $v$ (total uptake velocity) can be calculated for data in Fig. 5, as follows:

$$
\begin{aligned}
& v=\frac{f}{t} \cdot\left(S_{n}+A\right)_{i} v_{d}=K_{d}\left(S_{n}+A\right)_{i} \\
& \text { thus, } \frac{v_{d}}{v}=K_{d} \cdot t / f
\end{aligned}
$$

$v_{d} / V$ is the fraction of the total uptake velocity due to simple diffusion. $K_{t l}$ is not known, but an upper limit for it can be calculated if we assume that all uptake at $[\mathrm{A}]=10^{-3} \mathrm{M}$ is by simple diffusion.

Placing $v=v_{d}$ and $f / t=1.66 \times 10^{-4} \mathrm{~h}^{-1}$ at $[\mathrm{A}]=$ $10^{-3} \mathrm{M}$ (Fig. 5) in (1), and rearranging, $K_{d}=\mathrm{f} / \mathrm{t}=$ $1.66=10^{-4} \mathrm{~h}^{-1}$ For lower values of $\left[\mathrm{A}\right.$ ] in Fig. $5 \mathrm{v}_{d} / \mathrm{V}$ can be calculated from measured $t / f$ values and the calculated $K_{d} \cdot v_{d} / v$ was negligible for $[\mathrm{A}]=2.5 \times 10^{-9}$ $\mathrm{M}$ to $1 \times 10^{-1 i} \mathrm{M}(0.00012$ to 0.055$)$, increasing to 0.19 at $[\mathrm{A}]=1 \times 10^{-5} \mathrm{M}$. The actual contribution of diffusion would be less than that. As expected, the plot of the data in $10^{-9}-10^{-5} \mathrm{M}$ range was multiphasic after 'correcting' for diffusion (not shown).

Experimental results also show that the effect of simple diffusion is negligible at glucose concentrations up to at least $1 \times 10^{-5} \mathrm{M}$. The kinetic curves for samples from eutrophic desert ponds (Fig. 3) were perfect straight lines in the concentration range of $1 \times 10^{-9}-1 \times 10^{-1 .} \mathrm{M}$, indicating very low kinetic diversity; quite possibly only one species was present. Linearity of plots not only rules out very high $K_{t}$ transport systems but also discounts the influence of simple diffusion. Other investigators have reported linear $t / f$ vs [A] plots within narrow concentration ranges of glucose. Vaccaro and Jannasch (1966) found linear curves for 3 samples from the Atlantic Ocean using glucose additions of $1.39 \times 10^{-7}-1.53 \times 10^{-6} \mathrm{M}$. Hobbie and Crawford (1969) also obtained linear plots for a freshwater system in the glucose concentration range of $2.8 \times 10^{-6}-1 \times 10^{-5} \mathrm{M}$ (values read from their

Table 2. Kinetic parameters for glucose assımılation by a natural microbial assemblage in a seawater sample from the end of Scrupps Pier Data computed from the kinetic plots in Fig. 5. $\left[\right.$ A] : range of added glucose; $K_{t}$ : uptake constant: $S_{n}$ ambient glucose concentration; $V_{\text {max }}$ : maximum uptake ve-

locity; $T_{i}$ : turnover time for the ambient glucose pool

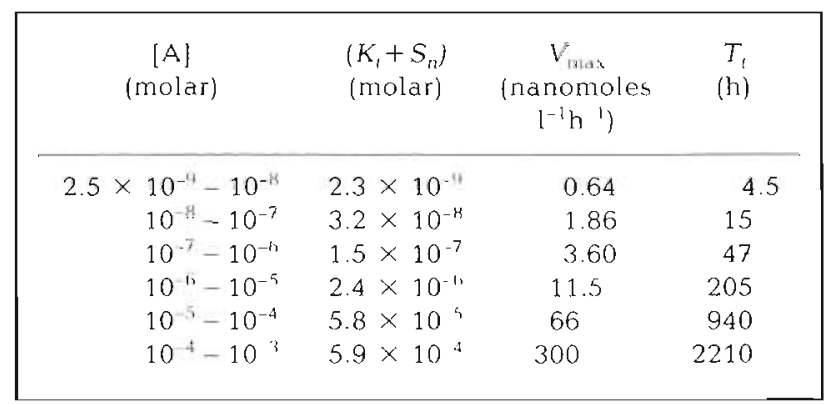


Fig. 1) Thus in this concentration range simple diffusion does not significantly affect the uptake by saturable systems. From the foregoing we conclude that the multiphasic kinetics observed by us are due to kinetic diversity and not a superposition of uptake and simple diffusion.

In seawater, then, there are bacteria with $K_{1}$ values as low as few nanomolar and as high as $10^{-5} \mathrm{M}$ (possibly higher). Bacteria with nanomolar $K_{i}$ (Hodson et al., 1979 ) and much higher $K_{\mathrm{r}}$ (Serratia marinorubra; $6.4 \times 10^{-6} \mathrm{Mi}$ Hodson and Azam, 1980) have been isolated from seawater Because of great selectivity of isolation media, and the possibility of bacterial contamination, the high $K_{t}$ isolates are often considered atypical if not suspect. However, for mixed natural marine bacterial assemblages, our data indicate that high $K_{i}$ bacteria may be normal components.

Turnover times at sub-nanomolar to millimolar glucose concentration (Figs 1, 2, 5; Table 2) are pertinent to a discussion of overall DOM turnover, as well as turnover in enriched microzones. Three different concentration regimes may be considered - low concentration in the bulk-phase, episodic high concentration microzones, and sustained high concentration microzones. Turnover of glucose at or near the low bulk phase concentrations (nanomolar) is very rapid ( $T_{t}=$ $9.5 \mathrm{~h}$; Fig. 5B). t/f increased greatly as [A] was increased. Thus, at $[\mathrm{A}]=10^{-6} \mathrm{M}$ and $10^{-3} \mathrm{M}$ t/f was 320 $\mathrm{h}$ and $6091 \mathrm{~h}$, respectively. Since molecular diffusion is a rapid process (seconds to minutes; Jackson, 1980) episodic 'peaks' of DOM would be utilized almost entirely after diffusion to low bulk-phase concentrations.

In sustained high concentration microzones (e.g. near a phytoplankter excreting DOM, or near a fecal pellet) bacteria with high $K_{t}$ high $V_{\text {max }}$ might accumulate. Consequently, DOM turnover in enriched microzones will be faster than predicted from our data, because our measurements assume homogeneous distribution of bacteria. This hypothesis suggests that a significant fraction of DOM might be utilized within sustained production microzones and not diffuse into the bulk phase. It also follows that the tracer technique (Williams and Askew, 1968; Azam and Holm-Hansen, 1973) will underestimate substrate uptake within sustained enriched production microzones if the tracer specific activity within such microzones is assumed to be the same as in the bulk phase.

We have no direct evidence for the validity of this working hypothesis. However, it is consistent with the intuitively obvious occurrence of high DOM in the production microzones, and the observed diversity of bacteria with respect to their uptake kinetics. Simply stated, we think that high $K_{t}$ high $V_{\text {max }}$ bacteria probably sense concentration gradients and accumulate where DOM is being produced. Episodic gradients will be too transient to cause such accumulation. Since low $K_{t}$ low $V_{\text {max }}$ systems are efficient at the bulk phase concentrations but saturate quickly at increasing concentrations, they are likely to dominate the bulk phase.

A weakness in our hypothesis is that it treats bacteria with different $K$, values as equivalent to uptake systems with different $K$, values. Some bacteria may possibly have both high and low $K_{1}$ (and $V_{\text {max }}$ ) uptake systems. Hodson et al. (1979) found that a marine isolate LNB-155 has a low capacity high affinity system $\left(K_{1}=7 \times 10^{-9} \mathrm{M}\right)$ and a high capacity low affinity system $\left(K_{t}=1.1 \times 10^{-7} \mathrm{M}\right)$. Such bacteria would be adapted to efficient substrate uptake over a broad range of concentrations.

Burnison and Morita (1974) measured chemically the concentrations $\left(S_{n}\right)$ of 16 different amino acids, and determined $\left(K_{1}+S_{n}\right)$ for each amino acid by the kinetic approach, in Lake Klamath, Oregon, USA. They found that $S_{n}$ was generally higher than $\left(K_{i}+S_{n}\right)$, and suggested that part of the amino acids may be adsorbed on particles and hence not available for bacterial uptake. Dawson and Gocke (1978) found a similar discrepancy for glucose and amino acid uptake kinetics in the Baltic Sea and Kiel Fjord. They also suggested that part of the substrate might be complexed and not available for uptake. An alternative for additional) explanation is that part of the substrate is utilized within enriched microzones by high $K$, bacteria. The tracer technique neither takes into account

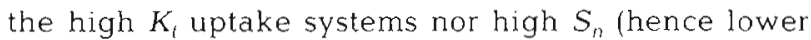
substrate specific activity) in the enriched microzones.

Other investigators have reported non-linear kinetic plots for uptake of sugars and amino acids (Vaccaro and Jannasch, 1966; Munro and Brock, 1968; Hamilton and Preslan, 1970; Crawford et al., 1974; Barvenik and Malloy, 1979). These plots were obtained over limited ranges of $[A]$ and therefore show much less non-linearity than observed by us. Some plots, (e.g. Vaccaro and Jannasch, 1966; Barvenik and Malloy, 1979) were irregular, or the slope increased instead of decreasing as in our plots. We do not have an explanation for irregular kinetics, but the increasing slope obtained by Barvenik and Malloy (1979) may, in principle, be explained by one dominant species exhibiting positive cooperativity (Levitzki and Koshland, 1969).

Williams (1973) simulated the consequences of kinetic diversity and concluded that extrapolation from the (near) linear part of the curve (high range of added substrate) would yield $T$, only $25 \%$ to $200 \%$ higher than that measured from a low concentration range. We found experimentally a 3.5 -fold increase in $T_{1}$ when measured at $10^{-r}-10^{-7} \mathrm{M}$ compared with $2.5 \times 10^{-4}-1 \times 10^{-8} \mathrm{M}$ glucose (Table 2). $T$ increased 500 -fold when we extrapolated in $1 \times 10^{-4}-1 \times 10^{-1}$ 
M range. The discrepancy is probably due to the range of added substrate used for linearization (relative to the range of $K_{t}$ ) in the computer simulation of Williams (1973)

In our experience non-linear plots of the form reported here are very common, if not the rule. On the contrary, other investigators have, during the last $15 \mathrm{y}$ reported 1 i ne a $r$ plots both for marine and freshwater environments. This apparent discrepancy between our results and the published work is because other investigators measured uptake kinetics over narrow concentration ranges. Clearly if we had arbitrarily chosen a narrow concentration range (Figs $1,2,5$ ), the computed values of kinetic parameters would depend on the concentration range chosen. This observation is pertinent to a discussion of the validity of the kinetic approach as applied to natural bacterial assemblages.

The kinetic approach is perhaps the most important and powerful technique in the study of in situ metabolism of bacterioplankton. The simplified kinetic model (Wright and Hobbie, 1965, 1966), however, implicitly assumes a selection in oligotrophic aquatic environments for very low $K_{t}$ bacteria, compatible with the extreme dilution of (bulk phase) DOM (Wright and Burnison, 1979). This leads to the expectation that the experimental data will (approximately) yield linear kinetic plots as though all bacteria had an identical $K_{t}$ and $V_{\text {max }}$ value. This expectation is often met when concentration-dependence is measured over a narrow range of added substrate. In the low (nanomolar) range of [A] (Wright and Hobbie, 1966; Gocke, 1977) the kinetic approach will yield $T_{t}$ as well as approximate $V_{\max }$ and $\left(K_{t}+S_{n}\right)$ of the low $K_{t}$ low $V_{\max }$ uptake systems. These systems are likely to be important in substrate turnover in the bulk phase. Analysis of uptake kinetics over a broad range of [A] should in addition provide insights into bacterial adaptations to varied nutrient regimes in seawater. This logical extension of the kinetic approach would necessitate the development of a model which takes into account the kinetic diversity of bacterioplankton.

Acknowledgements. We would like to thank J. W. Ammerman, J. Fuhrman and S. G. Horrigan for critically reading the manuscript, and P. J. LeB. Williams and J. T Hollibaugh for stimulating discussions. D. Osborn and J. Stearns provided invaluable assistance in the preparation of the manuscript. This research was supported by US Department of Energy Contract DE-AMO3-76SF00010.

\section{LITERATURE CITED}

Azam, F., Hodson, R. E. (1977). Size distribution and actıvity of marine microheterotrophs. Limnol. Oceanogr 22: $4.92-501$

Azam, F. Holm-Hansen, O. (1973). Use of tritiated substrates in the study of heterotrophy in seawater Mar Biol. 23: 191-196

Bada, J. L., Lee, C. (1977). Decomposition and alteration of organic compounds dissolved in seawiter Mar Chem. 5: 523-5.34

Barvenık, F. W. Malloy, S. C. (1979). Kinetic patterns of microbal amino acid uptake and mineralizatıon in marıne waters. Estuar coast. mar Sc! 8: 241250

Bennett, M. E., Hobbie, J. E. (1972). The uptake of glucose by Chlamydomonas sp. J. Phycol. 8: 392-398

Burnison, B. K., Morita, R. Y (1974). Heterotrophir potential for amino acid uptake in a naturally eutrophic lake. Appl Microbiol. 27: 488-495

Copping. A. E., Lorenzen, C. J. (1980). Carbon budget of a marine phytoplankton-herbivore system with ${ }^{14} \mathrm{C}$ as a tracer. Limnol. Oceanogr 25: 873-882

Crawford, C. C., Hobbie, J. E., Webb, K. L. (1974). The utilization of dissolved free amino acids by estuarine microorganisms. Ecology 55: 551-563

Dawson, R., Gocke, K. (1978). Heterotrophic activity in comparison to the free amino acid concentrations in Baltic Sea water samples. Oceanol. Acta 1. 45-54

Eadie, G. S. (1952). On the evaluation of the constants $V_{2 x, \ldots}$ and $K_{m}$ in enzyme reactions. Science, N. Y 116: 688

Ferguson, R. L., Rublee, P. (1976). Contribution of bacteria to standing crop of coastal plankton. Limnol. Oceanogr 21 . $141-145$

Fuhrman, J. (1981). Influence of method on the apparent size distribution of bacterioplankton cells: Epifluorescence microscopy compared to scanning electron microscopy. Mar Ecol. Prog. Ser 5: 103-106

Gocke, K. (1977). Comparison of methods for determining the turnover times of dissolved organic compounds. Mar Biol. 42: 131-1.41

Hamilton, R. D., Morgan, K. M., Strickland, J D. H. (1966) The glucose uptake kunetics of some marine bacteria. Can J. Microbiol. 12: 995-1003

Hamilton, R. D., Preslan, J. E. (1970). Observations on heterotrophic activity in the eastern tropical Pacific Ocean. I.umnol. Oceanogr 15: 395-401

Harrison, M. J., Wright, R. T., Morlta, R. Y (1971). Method for measurng mineralization in lake sediments. Appl. Microbıol. 21 698-702

Hobbie, J. E., Crawford, C. C. (1969). Respiration correction for bacterial uptake of dissolved organic compounds in natural waters. Limnol. Oceanogr 14: 528-532

Hodson, R. E. A Aam, F. (1980). Occurrence and characterizatıon of a phosphoenalpyruvate: Glucose phosphotransferase system in a marine bacterium Serratia marinorubra. Appl. environ. Microbiol. 38: 1086-1091

Hodson, R. E., Carluccl, A. F., Azam, F. (1979). Glucose transport in a low nutrient bacterium. Abstract. 79th Ann. Meeting Am. Soc. Microbiol. Los Angeles, USA

Hoftsee, B. H. J. (1952). On the evaluation of the constants $V_{m i}$ and $K_{m}$ in enzyme reactions. Science, $N$. Y 116 329-331

Hoppe, H.-G. (1976). Determination and propertıes of actively metabolizing heterotrophic bacteria in the sea, investigated by means of microautoradiography. Mar Biol. 369: 291-302

Jackson, G. J. (1980). Phytoplankton growth and zooplankton grazing in oligotrophic oceans. Nature, Lond. 284: $439-441$

Jannasch, H. W (1974). Steady state and the chemostat in ecology. Limnol. Oceanogr 19: 716-720

Lampert, W. (1978). Release of dissolved organic carbon by grazing zooplankton. Limnol. Oceanogr 23: 831-834 
Levitzki, A., Koshland, D. E. jr (1969). Negative cooperativity in regulatory enzymes. Proc. Nit. Acad. Sci. (USA) 62: 1121-1128

Mopper, K., Dawson, R., Liebuzeit, G., Ittekkot, V. (1980). The monosaccharide spectra of natural waters. Mar. Chem. 10: $55-66$

Munro, A. L. S., Brock, T D. (1968). Distinction between algal and bacterial utrlization of soluble substances in the sca J. gen. Microbiol. 51. 935-942

Nissen, P. (1977). Ion uptake in higher plants and KCI stimulation of plasmalemma adenosine triphosphatase - comparison of models. Physiologia Pl. 40: 205-214

Parsons, T R., Strickland, J. D. H. (1962). On the production of particulate organic carbon by heterotrophic processes in seawater. Deep Sea Res. 8: 211-222

Sheldon, R. W., Prakash, A., Sutcliffe, W. H. (1972). The size distribution of particles in the oceans. Limnol. Oceanogr 17: $327-340$

Sieburth, J. McN. (1976). Bacterial substrates and productivity in marine ecosystems. Ann. Rev. Ecol. Syst. 7: 259-285

Vaccaro, R. F., Jannasch, H. W (1966). Studies on heterotrophic activity in seawater based on glucose assimilation. Limnol. Oceanogr. 11: 596-607

Vaccaro, R. F., Hicks, S. E. Jannasch, H. W. Carey, F. G. (1968). The occurrence and role of glucose in seawater. Limnol. Oceanogr 13: 356-360
Williams, P. J. L. (1970). Heterotrophic utilization of dissolved organic compounds in the sea. 1. Size distribution of population and relationship between respiration and incorporation of growth substances. J. mar. biol. Ass. U. K. 50: $859-870$

Williams, P. J. L. (1973). The validity of the application of simple kinetic analysis to heterogeneous microbial populations. Limnol. Oceanogr. 18: 159-165

Williams, P. J. L. (1975). Biological and chemical aspects of dissolved organic material in seawater. In: Riley, J. P., Skirrow, G. (eds.) Chemical oceanography, Vol. 2, 2nd ed. Academic Press, London, pp. 301-363

Williams, P. J. L., Askew, C. (1968). A method of measuring the mineralization by microorganisms of organic compounds in seawater. Deep Sea Res. 15: 365-375

Wright, R. T., Hobbie, J. E. (1965). The uptake of organic solutes in lake water. Limnol. Oceanogr. 10: 22-28

Wright, R. T., Hobbie, J. E. (1966). Use of glucose and acetate by bacteria and algae in aquatic ecosystems. Ecology 47 : $447-464$

Wright, R. T., Burnison, B. K. (1979). Heterotrophic activity measured with radiolabeled organic substrates. In: Costerton, J. W., Colwell, R. R. (eds.) Native aquatic bacteria: Enumeration, activity, and ecology, ASTMSTP695, Am. Soc. for Testing Materials, Philadelphia, pp. 140-155 